University of New Hampshire

University of New Hampshire Scholars' Repository

$12-2002$

\title{
Combining remote sensing and ground census data to develop new maps of the distribution of rice agriculture in China
}

\author{
Steve Frolking \\ University of New Hampshire - Main Campus, steve.frolking@unh.edu \\ Jianjun Qiu \\ Chinese Academy of Agricultural Science \\ Stephen Boles \\ University of New Hampshire - Main Campus \\ Xiangming Xiao \\ University of New Hampshire - Main Campus \\ Jiyuan Liu \\ Chinese Academy of Sciences
}

See next page for additional authors

Follow this and additional works at: https://scholars.unh.edu/earthsci_facpub

\section{Recommended Citation}

Frolking, S., J. Qiu, S. Boles, X. Xiao, J. Liu, Y. Zhuang, C. Li, and X. Qin, Combining remote sensing and ground census data to develop new maps of the distribution of rice agriculture in China, Global Biogeochem. Cycles, 16(4), 1091, doi:10.1029/2001GB001425, 2002.

This Article is brought to you for free and open access by the Earth Sciences at University of New Hampshire Scholars' Repository. It has been accepted for inclusion in Earth Sciences Scholarship by an authorized administrator of University of New Hampshire Scholars' Repository. For more information, please contact Scholarly.Communication@unh.edu. 


\section{Authors}

Steve Frolking, Jianjun Qiu, Stephen Boles, Xiangming Xiao, Jiyuan Liu, Yahui Zhuang, Changsheng Li, and Xiaoguang Qin 


\title{
Combining remote sensing and ground census data to develop new maps of the distribution of rice agriculture in China
}

\author{
Steve Frolking, ${ }^{1}$ Jianjun Qiu, ${ }^{2}$ Stephen Boles, ${ }^{1}$ Xiangming Xiao, ${ }^{1,3}$ Jiyuan Liu, ${ }^{3}$ \\ Yahui Zhuang, ${ }^{4}$ Changsheng Li, ${ }^{1}$ and Xiaoguang Qin ${ }^{5}$ \\ Received 12 April 2001; revised 18 December 2001; accepted 4 April 2002; published 19 November 2002.
}

[1] Large-scale assessments of the potential for food production and its impact on biogeochemical cycling require the best possible information on the distribution of cropland. This information can come from ground-based agricultural census data sets and/ or spaceborne remote sensing products, both with strengths and weaknesses. Official cropland statistics for China contain much information on the distribution of crop types, but are known to significantly underestimate total cropland areas and are generally at coarse spatial resolution. Remote sensing products can provide moderate to fine spatial resolution estimates of cropland location and extent, but supply little information on crop type or management. We combined county-scale agricultural census statistics on total cropland area and sown area of 17 major crops in 1990 with a fine-resolution land-cover map derived from 1995-1996 optical remote sensing (Landsat) data to generate $0.5^{\circ}$ resolution maps of the distribution of rice agriculture in mainland China. Agricultural census data were used to determine the fraction of crop area in each $0.5^{\circ}$ grid cell that was in single rice and each of 10 different multicrop paddy rice rotations (e.g., winter wheat/ rice), while the remote sensing land-cover product was used to determine the spatial distribution and extent of total cropland in China. We estimate that there were 0.30 million $\mathrm{km}^{2}$ of paddy rice cropland; $75 \%$ of this paddy land was multicropped, and $56 \%$ had two rice plantings per year. Total sown area for paddy rice was 0.47 million $\mathrm{km}^{2}$. Paddy rice agriculture occurred on $23 \%$ of all cultivated land in China. INDEX TERMS: 0315 Atmospheric Composition and Structure: Biosphere/atmosphere interactions; 1615 Global Change: Biogeochemical processes (4805); KEYWORDS: paddy rice, maps, China, multicropping rotation, Landsat

Citation: Frolking, S., J. Qiu, S. Boles, X. Xiao, J. Liu, Y. Zhuang, C. Li, and X. Qin, Combining remote sensing and ground census data to develop new maps of the distribution of rice agriculture in China, Global Biogeochem. Cycles, 16(4), 1091, doi:10.1029/2001GB001425, 2002.

\section{Introduction}

[2] In the mid-1990s, paddy rice agriculture occupied about $22 \%$ of the world's grain-producing cropland and produced about $29 \%$ of the world's grain harvest (FAOSTAT, Statistical Database of the Food and Agricultural Organization of the United Nations, available at http:// apps.fao.org, hereinafter referred to as FAOSTAT database). China produced about one third of the world's rice on about

\footnotetext{
${ }^{1}$ Institute for the Study of Earth, Oceans, and Space, University of New Hampshire, Durham, New Hampshire, USA.

${ }^{2}$ Institute of Agricultural Resources and Regional Planning, Chinese Academy of Agricultural Sciences, Beijing, China.

${ }^{3}$ Institute of Geographical Sciences and Natural Resources, Chinese Academy of Sciences, Beijing, China.

${ }^{4}$ Research Center for Eco-Environmental Sciences, Chinese Academy of Sciences, Beijing, China.

${ }^{5}$ Institute of Geology and Geophysics, Chinese Academy of Sciences, Beijing, China.
}

Copyright 2002 by the American Geophysical Union. 0886-6236/02/2001GB001425 one fifth of the world's rice paddy land (FAOSTAT database). Thus, paddy rice agriculture in China accounted for about $5 \%$ of the world's total cropland and about $10 \%$ of the world's total grain harvest. Globally, rice paddies contribute about $11 \%$ of the total methane flux to the atmosphere [Prather et al., 1995]. Paddy rice agriculture in China is therefore of national and global significance for issues of both food security and climate change.

[3] There is a need for better information on the area and distribution of cropland in China. Official statistical data on cropland area for China [e.g., State Statistical Bureau, 1994], generated from ground-based agricultural census data assembled at the county scale, are known to underestimate actual cultivated area [State Statistical Bureau, 1994], perhaps by 20-40\% [Smil, 1999; Crook, 1993]. Yuyun and Zheng [2000] report that crop area estimates for China were accurate in 1960, but since that time only cropland losses have been tallied, while cropland area gains, generally from conversion of more marginal lands, have not. The result has been a fairly steady decline in total cropland area reported since 1960. Two reasons are given 
for this underreporting of cropland area: reducing tax burdens and artificially inflating crop productivity numbers [Yuyun and Zheng, 2000]. Colby et al. [1992] report a 7.5\% decline in area sown in grains from 1960 to 1990 in China.

[4] Analysis of satellite remote sensing data can be used to improve the estimate of cropland extent in China [e.g., Xiao et al., 2002b; Smil, 1999]. However, an agricultural census generally contains much more information than just total cropland area. For example, census data sets from China typically report sown area in each county for a range of different crop types (e.g., rice, maize, and cotton). Additionally, census data often contain information on other aspects of agricultural management, such as fertilizer use, irrigation, and animal populations.

[5] Roughly half of the cropland in China is multicropped, having two or more harvests per year. Multicropping can have significant consequences on the biogeochemical cycling of carbon and nitrogen in agroecosystems. Multicropped fields will generally receive much higher annual nitrogen fertilizer inputs than singlecropped fields, and thus can be expected to have higher annual nitrogen losses through leaching and denitrification [e.g., Vitousek et al., 1997]. Manure and crop litter inputs will also differ significantly across the spectrum of crop rotations, with consequences for carbon sequestration in soils [e.g., Havlin et al., 1990; Li et al., 1994] and methane emissions from paddy rice [e.g., Denier van der Gon and Neue, 1995; Sass et al., 1991]. Currently available largescale remote sensing analyses do not report the location or extent of multicropping. However, ground-based statistical data sets often contain information on both total land area in crops and planted or sown area of various crops, so estimates of land area in various multicrop rotations can be constructed.

[6] There are several existing maps of rice paddies in China. The 1:1,000,000 scale maps of China's land use given by $W u$ [1990] include a category of paddy rice, and the maps of the Second Soil Survey of China $[X i, 1998]$ include paddy soils as a category. These maps have finer spatial resolution $(\sim 1 \mathrm{~km})$ than the county census data (the scale of a county in China ranges over roughly 20-200 $\mathrm{km})$. Global 1-km-scale land-cover products sometimes include paddy rice as a legend category (e.g., the Seasonal Land-Cover Regions (SLCR) products derived from AVHRR [Loveland et al., 1995]). However, the SLCR products may not be reliable for mapping paddy rice in China [Frolking et al., 1999]. These existing maps do not contain information on single cropping versus multicropping, nor on the types of nonrice crops included in multicrop rotations on paddy land.

[7] Ramankutty and Foley [1998] and Hurtt et al. [2001] have combined the moderate $(1 \mathrm{~km})$ resolution IGBP DISCover global land cover product [Belward et al., 1999] with national and subnational census data on land use to develop gridded maps of cropland by correlating the two descriptions of the landscape. For China, because the official cropland area reported in the census is a significant underestimation, a correlation approach will not work well. Instead, we make the assumption that fine-resolution remote sensing analyses (scale $\sim 0.1 \mathrm{~km}$ ) provide a good estimate of the location and extent of cropland, and the agricultural census data provide a good estimate of the relative areas planted in each major crop. To develop new maps of the distribution of rice agriculture in China, describing both spatial extent and variation in crop rotation, we combined detailed information on the distribution of single and multicrop rotation areas from a county-scale agricultural census with a new estimate of the distribution of cropland area based on fine-resolution Landsat remote sensing data. We generated $0.5^{\circ}$ resolution maps for mainland China of the area within each grid cell in 11 different crop rotations that include rice, and also 38 other single-crop and multicrop rotations.

\section{Data Sets and Methods}

\subsection{Agricultural Census Data}

[8] County-level agricultural census data for China in 1990 were acquired from the Eco-Environmental Database of the Research Center for Eco-Environmental Sciences, Chinese Academy of Sciences. The database contains county statistics on sown area for 17 major crops, total cropland area, total sown area, nitrogen fertilizer use, and livestock and rural human populations for counties in mainland China; no data were available for Taiwan, Hong Kong, or Macao. Provincial and national crop area totals derived from this county-scale data set are generally within $1 \%$ of official areas reported by the State Statistical Bureau [1994]. This county-scale database has been used previously for an analysis of crop residue production in China [Zhuang et al., 1996], compared with moderate resolution remote sensing land cover maps [Frolking et al., 1999], and used to generate estimates of $\mathrm{N}_{2} \mathrm{O}$ emissions from China's croplands [Li et al., 2001]. Hereinafter, this data set will be called AC90.

\subsection{Generating Crop Rotation Area Estimates From the Agricultural Census Data}

[9] Harvesting two or more crops from a single plot in a single year (multicropping) is common in much of central and southern China. Cropland area data reflect the actual total land area supporting crops, while sown area data reflects the area of land planted with each crop. Thus, a summation of all sown area for a region will double-count land that is double cropped, and triple-count land that is triple cropped. In AC90 some counties in China report sown area to be nearly triple the crop area (i.e., almost all cropland is multicropped), and the AC90 total sown area for China is 57\% greater than the AC90 total cropland area, consistent with the official estimates of aggregate multicropping in China reported by the State Statistical Bureau [1994].

[10] AC90 contains county-scale agricultural data on the total sown areas of individual crops and the total cropland area, but not areas in any specific crop rotation (e.g., winter wheat/maize). To estimate the area of specific crop rotations in each county, it was necessary to partition the total sown area into a set of crop rotations. While doing this, it was important to keep each county's total cropland area and the sown area of each individual crop in each county consistent with the AC90 database. 
Table 1. Regional Multicropping Rotations

\begin{tabular}{|c|c|c|}
\hline Region $^{a}$ & Provinces $^{\mathrm{a}}$ & Multicrop Rotation Priorities ${ }^{\mathrm{b}}$ \\
\hline I. Northeast/north ${ }^{\mathrm{c}}$ & $\begin{array}{l}\text { Heilongjiang, Inner Mongolia, Jilin, Liaoning, } \\
\text { and northern Xinjiang and Gansu }\end{array}$ & $\begin{array}{l}\text { predominantly single cropping; rice/vegetable, rapeseed/ } \\
\text { vegetable, vegetable/maize, maize/soybean, potato/soy- } \\
\text { bean, rice/rapeseed, rapeseed/maize, vegetable/vegeta- } \\
\text { ble/vegetable. }\end{array}$ \\
\hline II. North China Plain and central/western & $\begin{array}{l}\text { Beijing, Hebei, Henan, Ningxia, Qinghai, } \\
\text { Shaanxi, Shandong, Shanxi, Tianjin, Tibet, } \\
\text { and southern Xinjiang and Gansu }\end{array}$ & $\begin{array}{l}\text { winter wheat/rapeseed, winter wheat/maize, winter wheat/ } \\
\text { rice, winter wheat/vegetable, rice/rapeseed, rapeseed/ } \\
\text { maize, vegetable/maize, rice/vegetable, vegetable/vege- } \\
\text { table/vegetable, maize/soybean, winter wheat/soybean, } \\
\text { soybean/hay, winter wheat/potato, rice/oats, potato/ } \\
\text { soybean, winter wheat/cotton, oats/soybean, rice/soy- } \\
\text { bean. }\end{array}$ \\
\hline III. Southwest & Guizhou, Sichuan, and Yunnan & $\begin{array}{l}\text { rice/rice/alfalfa, potato/vegetable/vegetable, winter wheat/ } \\
\text { rapeseed, winter wheat/maize, winter wheat/rice, winter } \\
\text { wheat/vegetable, rice/rapeseed, rapeseed/vegetables, } \\
\text { vegetable/maize, rice/vegetable, vegetable/vegetable/ } \\
\text { vegetable, maize/soybean, winter wheat/soybean, soy- } \\
\text { bean/hay, winter wheat/potato, rice/oats, potato/soy- } \\
\text { bean, oats/soybean, potato/maize, rapeseed/soybean, } \\
\text { rice/rice, potato/potato. }\end{array}$ \\
\hline IV. Middle and lower Yangtze River & $\begin{array}{l}\text { Anhui, Hubei, and Hunan, Jiangsu, Jiangxi, } \\
\text { Shanghai, and Zhejiang }\end{array}$ & $\begin{array}{l}\text { rice/rice/alfalfa, rice/rice/winter wheat, potato/vegetable/ } \\
\text { vegetable, winter wheat/rapeseed, winter wheat/maize, } \\
\text { winter wheat/rice, winter wheat/vegetable, rice/rape- } \\
\text { seed, rapeseed/maize, vegetable/maize, rice/vegetable, } \\
\text { vegetable/vegetable/vegetable, maize/soybean, winter } \\
\text { wheat/soybean, soybean/hay, winter wheat/potato, rice/ } \\
\text { oats, potato/soybean, oats/soybean, potato/maize, rape- } \\
\text { seed/soybean, rapeseed/cotton, rice/soybean, rice/rice. }\end{array}$ \\
\hline V. Southern China & Fujian, Guangdong, Guangxi, and Hainan & $\begin{array}{l}\text { rice/rice/alfalfa, rice/rice/rapeseed, rice/rice/vegetable, } \\
\text { rice/rice, potato/vegetable/vegetable, winter wheat/ } \\
\text { rapeseed, winter wheat/maize, winter wheat/rice, } \\
\text { winter wheat/vegetable, rice/rapeseed, rapeseed/maize, } \\
\text { vegetable/maize, rice/vegetable, vegetable/vegetable/ } \\
\text { vegetable, maize/soybean, winter wheat/soybean, soy- } \\
\text { bean/hay, winter wheat/potato, rice/oats, potato/soy- } \\
\text { bean, oats/soybean, rice/soybean, potato/potato, maize/ } \\
\text { maize. }\end{array}$ \\
\hline
\end{tabular}

a See Figure 1.

${ }^{\mathrm{b}}$ This column lists each region's multicrop rotations by priority (see text for discussion).

${ }^{\mathrm{c}}$ All wheat planted in this region is considered to be spring wheat; throughout the rest of China it is considered to be winter wheat.

[11] The first step was to calculate the difference between the total crop area and the total sown area in a county. If the reported crop area was larger than the reported sown area, the excess crop area was assigned to the fallow category, and all sown crops were assumed to be in a single-crop rotation. If the total sown area was larger than the total crop area, the excess sown area was set equal to the area of multicropping, and was disaggregated into regionally appropriate crop rotations, as discussed below.

[12] The second step was to establish a set of crop rotation priorities. For this, we considered five agro-climatic regions in China: the Northeast and arid North, the North China Plain and Central and Western China, the middle and lower reaches of the Yangtze River, Southern China, and Southwestern China (Table 1 and Figure 1). We based our crop rotation priorities (Table 1) on surveys and statistical data collected by the Institute of Agricultural Resources and Regional Planning, Chinese Academy of Agricultural Sciences, and also on provincial agricultural statistical yearbooks, such as the Hubei Province Agricultural Statistical Yearbook [Editorial Committee, 1991].

[13] There was little multicropping in the Northeast and arid North (Region 1 in Figure 1 and Table 1), and that which occurred was primarily a grain/vegetable or grain/ soybean rotation. To fit the crop and sown areas, small areas of rice/rapeseed and rapeseed/maize were necessary in 10 of the 325 counties in this region. In the North China Plain and Central and Western China (Region 2), there was a mix of single and double cropping, and a triple cropping of vegetables. The dominant multicrop rotations were double croppings of winter wheat combined with rapeseed, maize, rice, or vegetables. Southwestern China (Region 3) had a mixture of single, double, and triple cropping. In the middle and lower reaches of the Yangtze River (Region 4), there was primarily double and triple cropping, with an emphasis on paddy rice. Southern China (Region 5) also had mostly double and triple cropping. The dominant multicrop rotations in southern China were triple croppings of double rice combined with alfalfa, rapeseed, or vegetables. In addition, a few specific priorities and rotations were assigned to certain provinces, such as rapeseed/cotton only in Hunan, Hubei, and Jiangxi Provinces, and maize/maize only for Southern China. We considered six triple-cropping rotations, four with double rice and two with double vegetable: rice/rice/alfalfa, rice/rice/rapeseed, rice/rice/vegetables, rice/ 


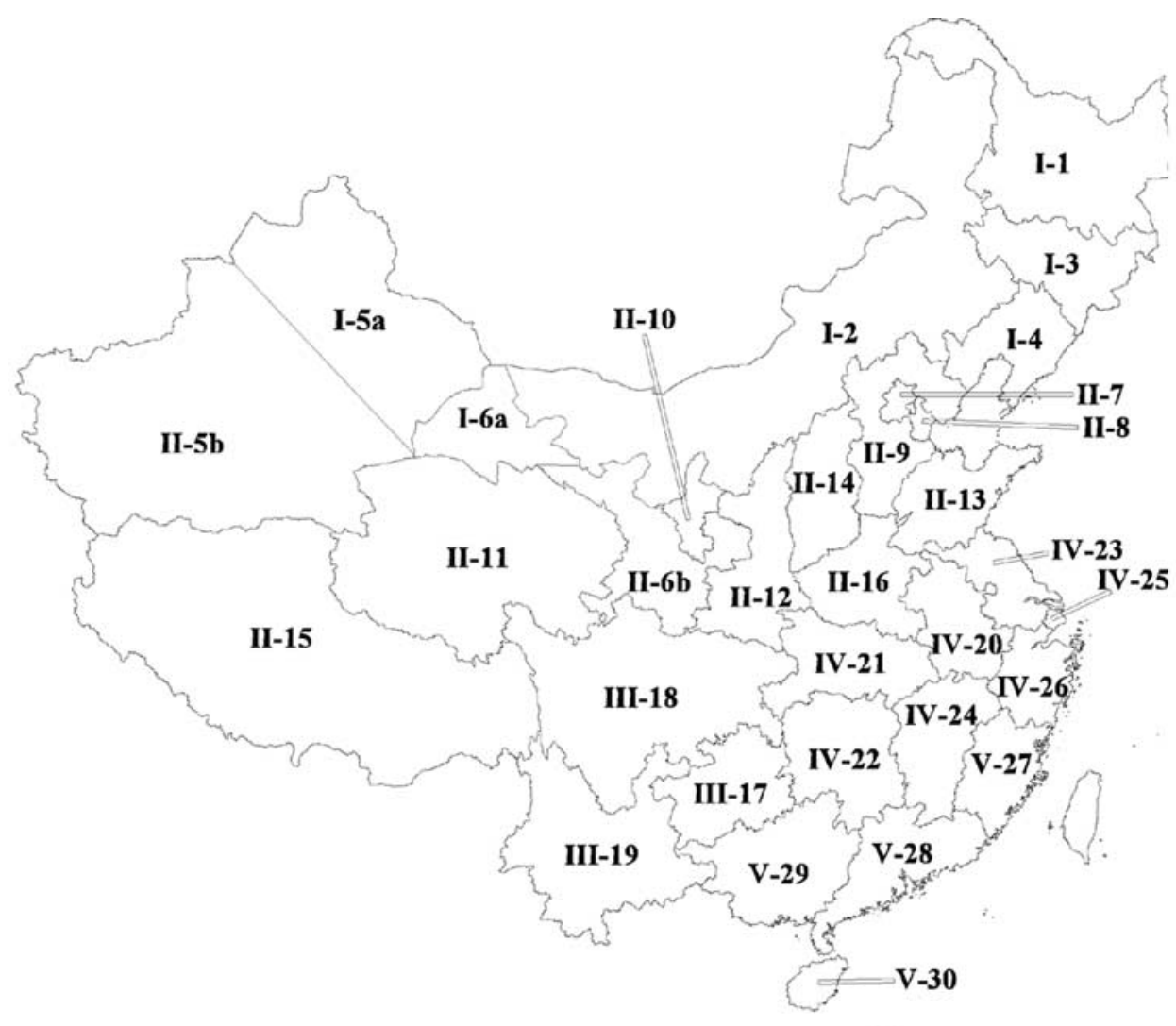

Figure 1. Provincial boundaries of China, and the 5 crop-zone regions for assigning multicropping priorities (see Table 1). Each province is labeled as "region-province." The region codes are: I, North and Northeast; II, North China Plain and Central and West; III, Southwest; IV, Middle and Lower Yangtze River; V, South. The province codes are: 1, Heilongjiang; 2, Inner Mongolia; 3, Jilin; 4, Liaoning; 5a, northern Xinjiang; 5b, southern Xinjiang; 6a, northern Gansu; 6b, southern Gansu; 7, Beijing; 8, Tianjin; 9. Hebei; 10, Ningxia; 11, Qinghai; 12, Shaanxi; 13, Shandong; 14, Shanxi; 15, Tibet; 16, Henan; 17, Guizhou; 18, Sichuan; 19, Yunnan; 20, Anhui; 21, Hubei; 22, Hunan; 23, Jiangsu; 24, Jiangxi; 25, Shanghai; 26, Zhejiang; 27, Fujian; 28, Guangdong; 29, Guangxi; 30, Hainan. Note that Taiwan (large island off southeast coast) is not included in our analysis.

rice/wheat, vegetable/vegetable/potato, and triple vegetable. These represent simple and common modes of triple cropping. We ignored less common multicrop rotations, including all multicrop rotations with four or more plantings per year, because their areas would be quite small at the national scale, and the number of variations would be quite large. Many multicrop rotations occur in suburban counties, and consist of sequential plantings of different vegetables grown for urban markets.

[14] For all counties with a total sown area greater than the total cropland area, we then partitioned the excess sown area into allowable crop rotations in an iterative procedure according to the crop rotation priorities in the specific region (Table 1). This generated the area in each crop rotation in each county, $a_{k n}$, where the subscript $k$ refers to the county, and the subscript $n$ refers to the crop rotation. This preserved total cropland area and individual crop sown area, i.e., the data we had to work with. However, there may be discrepancies between these results and the real situation, as we could use only very general rules for prioritizing crop rotations. Finally, for each county we calculated the fractional area in each crop rotation

$$
\beta_{k, n}=\frac{a_{k, n}}{\sum_{n} a_{k, n}},
$$

where $\beta$ is the fraction of total cropland area in county $k$ that is in crop rotation $n$. Note that for each county,

$$
\sum_{n} \beta_{k, n}=1.0
$$

These $\beta_{k, n}$ were subsequently used to partition total cropland area, as determined by classification of fineresolution remote sensing, following the methodology outlined below.

\subsection{Remote Sensing Data}

[15] In the late 1990s, the Chinese Academy of Sciences organized eight research institutions and about 100 scientists to conduct its second national-scale land-cover and land-use classification project, using 520 Landsat TM 
images of China, primarily from 1995/1996 [Liu, 1996]. The images were geo-referenced and ortho-rectified, using field-collected ground control points and fine-resolution digital elevation models, and have an average geoposition error of $\pm 50 \mathrm{~m}$. Visual interpretation and digitalization of TM images at the $1: 100,000$ scale were conducted to generate thematic maps of land use and land cover. A hierarchical classification system of 25 land-cover classes was applied, including two cropland classes (paddy fields and nonflooded cropland). Interpretation of TM images and validation of land-cover classification were based on extensive field surveys. The original 1:100,000 scale Map of Land Cover in China generated in this National Landcover Database (NLCD) project estimated that there were 1.74 million $\mathrm{km}^{2}$ cropland area in China. However, this initial analysis did not consider the fraction of noncultivated land within a polygon of cropland (e.g., narrow roads and footpaths, small rice paddy levees, irrigation channels, and residential areas). To account for this fraction of noncultivated land, the NLCD project developed a stratified, multilayer sampling design that divided China into 870 sampling zones, and acquired aerial photos for each sampling zone. The interpretation of these aerial photos showed that the fraction of noncultivated land in a cropland polygon ranged between 0.2 and 0.3 for most of the 816 sampling zones where the original 1:100,000 scale land cover maps indicated that there was cropland. After applying each zone's fraction of noncultivated land to the original 1:100,000 Map of Land Use in China, the NLCD project generated an estimate of 1.32 million $\mathrm{km}^{2}$ total cropland area in China, with 0.36 million $\mathrm{km}^{2}$ of this classified as rice paddy. The vector land-use map (1:100,000 scale) was converted into a 1-km gridded database that still captures all of the fineresolution land cover information by calculating percent fractional cover within each 1-km grid cell [Tang, 2000; Zhang et al., 2000; Liu et al., 2001]. In this study, we used the $1-\mathrm{km}$ gridded database, hereinafter called NLCD-96.

\subsection{Filling in Data Gaps}

[16] One inconsistency and one data gap had to be reconciled. First, some counties that had no cropland area reported in AC90 did have fractional cropland area values for some of their 1-km pixels in NLCD-96. In our methodology, NLCD-96 defines the cropland area, so all counties with NLCD-96 cropland must be assigned crop rotation fractional values $\left(\beta_{k, n}\right)$, but these could not be calculated from the AC90 data if no crop areas were reported. We set $\beta_{k, n}$ values for each of these counties equal to the mean of $\beta_{k, n}$ for all neighboring (abutting) counties, under the assumption that distribution in crop rotations was relatively constant across these scales $(\sim 10-100 \mathrm{~km})$. The cropland area affected by this was $1.6 \%$ of the national total. Second, for small regions in Heilongjiang, Liaoning, and Zhejiang Provinces in northeastern China, the NLCD-96 product had only the original cropland area estimates, but did not have data adjusted for noncropland features. For these areas $(1.2 \%$ of total land area in China) we used the noncropland adjustment factors derived for the neighboring $0.5^{\circ}$ grid cells, again under the assumption that fraction of crop area that was not cultivated (footpaths, irrigation channels, etc.) was relatively constant across these scales $(\sim 50-100 \mathrm{~km})$.

\subsection{Algorithm to Combine Census and Remote Sensing Data}

[17] We overlaid a $0.5^{\circ} \times 0.5^{\circ}$ grid on the $1-\mathrm{km}$ NLCD96 cropland fraction map and calculated the total cropland area in each $0.5^{\circ} \times 0.5^{\circ}$ cell, $C_{j}$,

$$
C_{j}=\sum_{x \in j} c_{x},
$$

where $j$ is the grid cell index ( $j=1$ to 4163 ), and $c_{x}$ is the fraction of each 1-km NLCD-96 pixel, $x$, that is classified as cropland (paddy plus nonflooded) in the NLCD-96 raster database. We also generated a remote sensing based estimate of paddy rice area on a $0.5^{\circ}$ grid, $P_{j}$,

$$
P_{j}=\sum_{x \in j} p_{x},
$$

where $j$ is the grid cell index and $p_{x}$ is the fraction of each 1$\mathrm{km}$ NLCD-96 pixel, $x$, that is classified as paddy rice. We did not use this paddy data to generate our maps of rice agriculture, but as a separate map for comparison with our final product.

[18] We then overlaid this same $0.5^{\circ}$ grid with a county boundary map of China (Consortium for International Earth Science Information Network, The China Time Series Administrative Regions GIS Data; 1:1M, County Level, prepared by CIESIN, the Chinese Academy of Surveying and Mapping, and China in Time and Space (University of Washington), available at http://sedac.ciesin.org/china/ $\mathrm{admin} / \mathrm{bnd} 90 / \mathrm{bnd} 90 \mathrm{html})$. The intersection of these two maps generated $\sim 11,000$ polygons, each polygon representing the portion of a particular county within a particular grid cell. In some cases a small county was completely within a single $0.5^{\circ}$ grid cell, or a large county occupied an entire $0.5^{\circ}$ grid cell, but generally a grid cell consisted of parts of several counties. We overlaid this new polygon map on the 1-km NLCD-96 cropland fraction map, and, as above, calculated the total cropland area in each polygon, $\tilde{C}_{j, k}$,

$$
\tilde{C}_{j, k}=\sum_{x \in j, k} c_{x}
$$

where $k$ is the county index ( $k=1$ to 2473 ), and the double index $(j, k)$ identifies the polygon whose land area is common to both county $k$ and grid cell $j$. We then determined the fraction of total cropland in grid cell $j$ that lies within county $k, f_{j, k}$ as

$$
f_{j, k}=\frac{\tilde{C}_{j, k}}{\sum_{\mathrm{k}^{*} \in j} \tilde{C}_{j, k}{ }^{*}},
$$

where the sum is over all counties, $k^{*}$, that intersect with grid cell $j$. We then generated a set of crop rotation distributions for each $0.5^{\circ}$ grid cell, $\gamma_{j, n}$, as the area-weighted average of the contributing counties,

$$
\gamma_{j, n}=\sum_{k \in j} f_{j, k} \cdot \beta_{k, n},
$$


Table 2. Cropland Rotation Areas $\left(1000 \mathrm{~km}^{2}\right)$ in China

\begin{tabular}{|c|c|}
\hline Crop & Area \\
\hline \multicolumn{2}{|c|}{ Rice } \\
\hline Rice/rice/alfalfa & 50. \\
\hline Rice/rice/rapeseed & 42. \\
\hline Rice/rice/vegetable & 11. \\
\hline Rice/rice/wheat & 20. \\
\hline Rice/oat & 22. \\
\hline Rice/rapeseed & 3.5 \\
\hline Rice/rice & 45. \\
\hline Rice/soybean & 1.6 \\
\hline Rice/vegetable & 4.3 \\
\hline Rice/wheat & 27. \\
\hline Rice & 76. \\
\hline Total land areab & 300. \\
\hline Total rice sown area ${ }^{c}$ & 470 \\
\hline
\end{tabular}

Vegetable/vegetable/potato

Nonrice Multicrop

Vegetable/vegetable/vegetable

Maize/maize

Maize/soybean

Soybean/oat

Potato/maize

Potato/potato

Potato/soybean

Rapeseed/maize

Rapeseed/cotton

Rapeseed/soybean

Rapeseed/vegetable

Soybean/non-legume hay

Vegetable/maize

Wheat/maize

Wheat/cotton

Wheat/potato

Wheat/rapeseed

Wheat/soybean

Wheat/vegetable

Total land area ${ }^{\mathrm{b}}$

Total sown area

19.

1.2

11.

0.83

14.

8.9

3.6

3.6

1.4

0.46

1.3

$<0.010$

2.2

110.

6.0

7.5

66.

16.

3.3

280 .

580 .

\begin{tabular}{|c|c|}
\hline \multicolumn{2}{|c|}{ Nonrice Single Crop } \\
\hline Alfalfa & 5.7 \\
\hline Beets & 10. \\
\hline Maize & 150 \\
\hline Cotton & 56. \\
\hline Millet & 33. \\
\hline Nonlegume hay & 0.010 \\
\hline Oats & 82. \\
\hline Potato & 65. \\
\hline Rapeseed & 35. \\
\hline Sorghum & 20. \\
\hline Soybean & 74. \\
\hline Sugarcane & 12. \\
\hline Sunflower & 6.0 \\
\hline Tobacco & 0.014 \\
\hline Vegetable & 22. \\
\hline Wheat & 140. \\
\hline Fallow & 32. \\
\hline Total land area ${ }^{b}$ & 740 \\
\hline Total sown area & 740 . \\
\hline
\end{tabular}

${ }^{\mathrm{a}}$ Excludes Taiwan, Hongkong, and Macao.

${ }^{\mathrm{b}}$ Totals may not match sum due to rounding. All values are reported with two significant figures.

${ }^{\mathrm{c}}$ Total sown area of all crops in these rotations is $660,000 \mathrm{~km}^{2}$.

where the subscript $n$ refers to the 49 crop rotations in the AC90 database (note that $\Sigma_{n} \gamma_{j, n}=1.0$ ). Then the area in each $0.5^{\circ}$ grid cell in crop rotation $n, C_{j, n}$, was calculated as

$$
C_{j, n}=\gamma_{j, n} C_{j}
$$

This new set of crop areas preserved the total cropland area determined from remote sensing (NLCD-96) and the fractional areas in each crop rotation derived from the census data (AC90).

\section{Results}

[19] The new database contains 11 crop rotations that include rice, and we estimated that there were 0.30 million $\mathrm{km}^{2}$ of land in China planted in rice at least once per year (Table 2). One quarter of this land was planted as single rice, $15 \%$ was under a double-crop rotation with two rice plantings per year (rice/rice), 19\% was under a double-crop rotation with a single rice planting (rice/other), and $41 \%$ was under a triple-crop rotation with two rice plantings per year (rice/rice/other). The total sown area for rice was 0.47 million $\mathrm{km}^{2}$. We estimate that paddy rice agriculture occurred on $23 \%$ of all cultivated land in China.

[20] The single rice rotation occurred throughout eastern China, except for Hubei Province (Figure 2a). The dominant regions were in the river valleys of the northeast (Liaoning, Jilin, and Heilongjiang Provinces), the western edge of the Sichuan Basin, Yunnan Province, and southern Henan province. There were small areas of single rice in the northwest and in northern Ningxia Province in central China. Double rice was primarily in the Sichuan Basin in eastern Sichuan Province, along the southern coast, and on Hainan Island (Figure 2b). Double cropping with a single rice planting was located predominantly in central China (Jiangsu and Henan Provinces), with some area in the southcentral provinces of Sichuan, Guizhou, and Yunnan, and minor occurrences in the northeast (Figure 2c). Triple cropping with two rice plantings was common in south-central China (Anhui, Hubei, Zhejiang, and Jiangxi Provinces; Figure 2d). Rotations with two rice plantings were not significant north of the middle and lower reaches of the Yangtze River.

[21] In aggregate, rice agriculture occurred throughout eastern China, but was concentrated in southern China, the Sichuan Basin, and in the northeast (Figure 3a). The middle and lower reaches of the Yangtze River and the associated large lake basins (Dongting $\mathrm{Hu}$, Poyang $\mathrm{Hu}$, and Tai $\mathrm{Hu}$ ) were the regions with the highest concentration of rice agriculture.

\section{Discussion and Conclusions}

[22] Our methodology used land-cover classifications from fine-resolution remote sensing imagery to determine the extent and location of cropland area in China. This Landsat TM-based product [Liu et al., 2001; Zhang et al., 2000] had two cropland classes (paddy and nonflooded), which were aggregated to total cropland. We partitioned this total cropland into 49 different single and multicrop rotations, based on county-scale statistical information for mainland China on the sown areas for 17 major crops. Our new cropland area estimates preserve the total cropland area from the remote sensing analysis (1.32 million $\mathrm{km}^{2}$ ). This is $\sim 40 \%$ higher than official cropland area totals [State Statistical Bureau, 1994], which is roughly consistent with other estimates of underreporting in official cropland area 
(a)

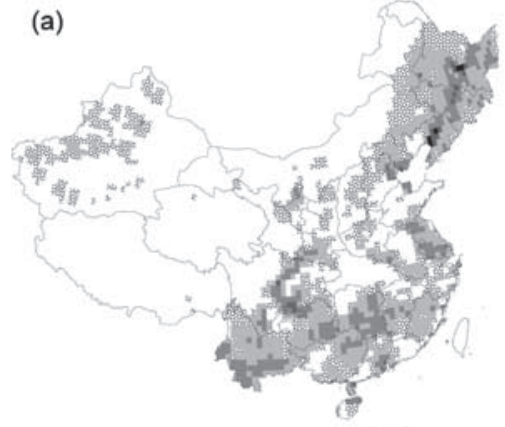

(c)

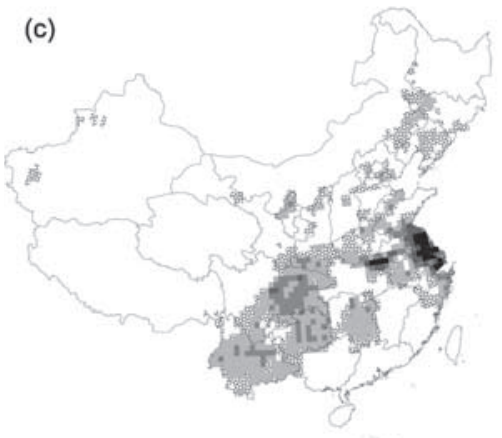

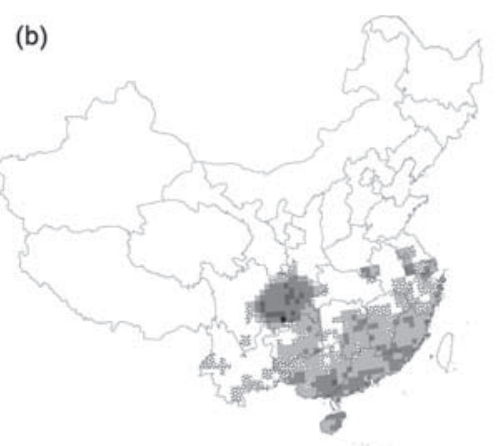

(b)

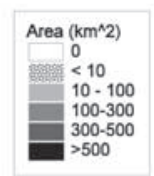

(d)

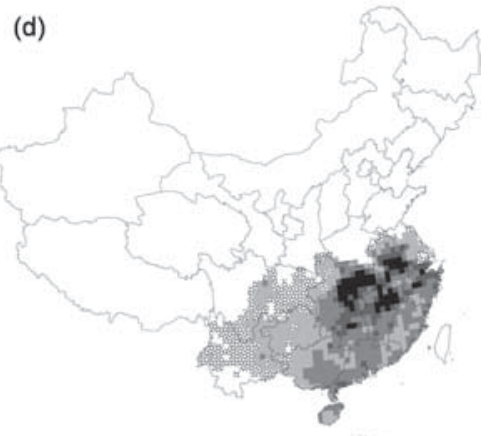

Figure 2. Maps of the distribution of rice crop rotations in China: (a) single rice; (b) double rice (double-cropping); (c) rice and another crop (double-cropping); and (d) double rice and another crop (triple-cropping). All maps are $0.5^{\circ}$ resolution, and the gray scale refers to the land area within each grid cell that is classified in the specified rotation. Multicropped land is not weighed more heavily than singlecropped land. Note that Figure $2 \mathrm{c}$ is an aggregation of five "rice/other crop" rotation areas, and Figure $2 \mathrm{~d}$ is an aggregation of four "rice/rice/other crop" rotation areas (see Table 2).

statistics [e.g., Crook, 1993; Fu et al., 1993; Smil, 1999]. Verburg and Denier van der Gon [2001] also estimated 1.32 million $\mathrm{km}^{2}$ of cultivated land in China in 1991. Our new estimate of the paddy-rice land area in China ( 0.30 million $\mathrm{km}^{2}$ ) is $18 \%$ greater than reported in official statistics [State Statistical Bureau, 1994], 16\% less than estimated by optical remote sensing (Table 3 [see also Liu et al., 2001]), and the same as the estimate by the Second Soil Survey of China [Xi, 1998].

[23] Our estimate for total rice sown area (0.47-million $\mathrm{km}^{2}$ ) is $42 \%$ greater than the official estimate (Table 3, [State Statistical Bureau, 1994]), and equal to the estimate of Verburg and Denier van der Gon [2001]. The NLCD-96 remote sensing product does not provide an estimate of total rice sown area. Our analysis arrives at a larger sown-area: land-area ratio $(0.47 / 0.30=1.57)$ than the official statistical value $(0.33 / 0.26=1.27$ [State Statistical Bureau, 1994]). This arises because we assigned high priorities to the "rice/ rice/other crop" and "rice/rice" rotations in Southern China and the middle and lower reaches of the Yangtze River basin (Table 2), and thus placed much of the rice-sown area into "double rice" rotations. When we applied our crop rotation fractions $\left(\beta_{k, n}\right)$ to the AC90 county crop area data, we arrived at a rice sown area estimate of 0.33 million $\mathrm{km}^{2}$ (i.e., consistent with the State Statistical Bureau (SSB) values, and preserving total sown area), but a rice land area estimate of only 0.21 million $\mathrm{km}^{2}$, about $20 \%$ less than the SSB value (Table 3).
[24] Official statistics on the total sown area of rice in China [SSB, 1994], and Food and Agricultural Organization of the United Nations (FAO) statistics on harvested area of rice in China (FAOSTAT database) agree that between 1980 and 1990 , the area varied by $<10 \%(1980=0.34 ; 1985=$ $0.32 ; 1990=0.33$ million $\mathrm{km}^{2}$ ), and the FAO total for 1995 is 0.31 million $\mathrm{km}^{2}$. The magnitude of this reported interannual variability is significantly smaller than the discrepancies between our new estimate of sown area and the officially reported areas. Smil [1999] estimated that China was losing about 0.005 million $\mathrm{km}^{2}$ of cropland each year through conversion to other land uses. Verburg and Denier van der Gon [2001] predict that China will lose $8 \%$ of its cultivated land and $13 \%$ of its sown area of rice between 1991 and 2010. Seto et al. [2000] analyzed Landsat TM satellite images from 1990 and 1996 for a 10-county region in the rapidly developing Pearl River Delta region in Guangdong Province in southern China. Their landcover classification estimated the agricultural land area in this region $\left(0.0067\right.$ million $\left.\mathrm{km}^{2}\right)$ to be more than twice that reported in official statistics, and that about $13 \%$ of this agricultural land was converted to nonagricultural use between 1990 and 1996. Land-use conversion from cropland to nonagricultural use in this region is likely to be among the most rapid of all regions of China [Seto et al., 2000]. While there will be some inherent uncertainty in our methodology because we combine crop census statistics from 1990 with remote sensing area estimates from 1995/ 

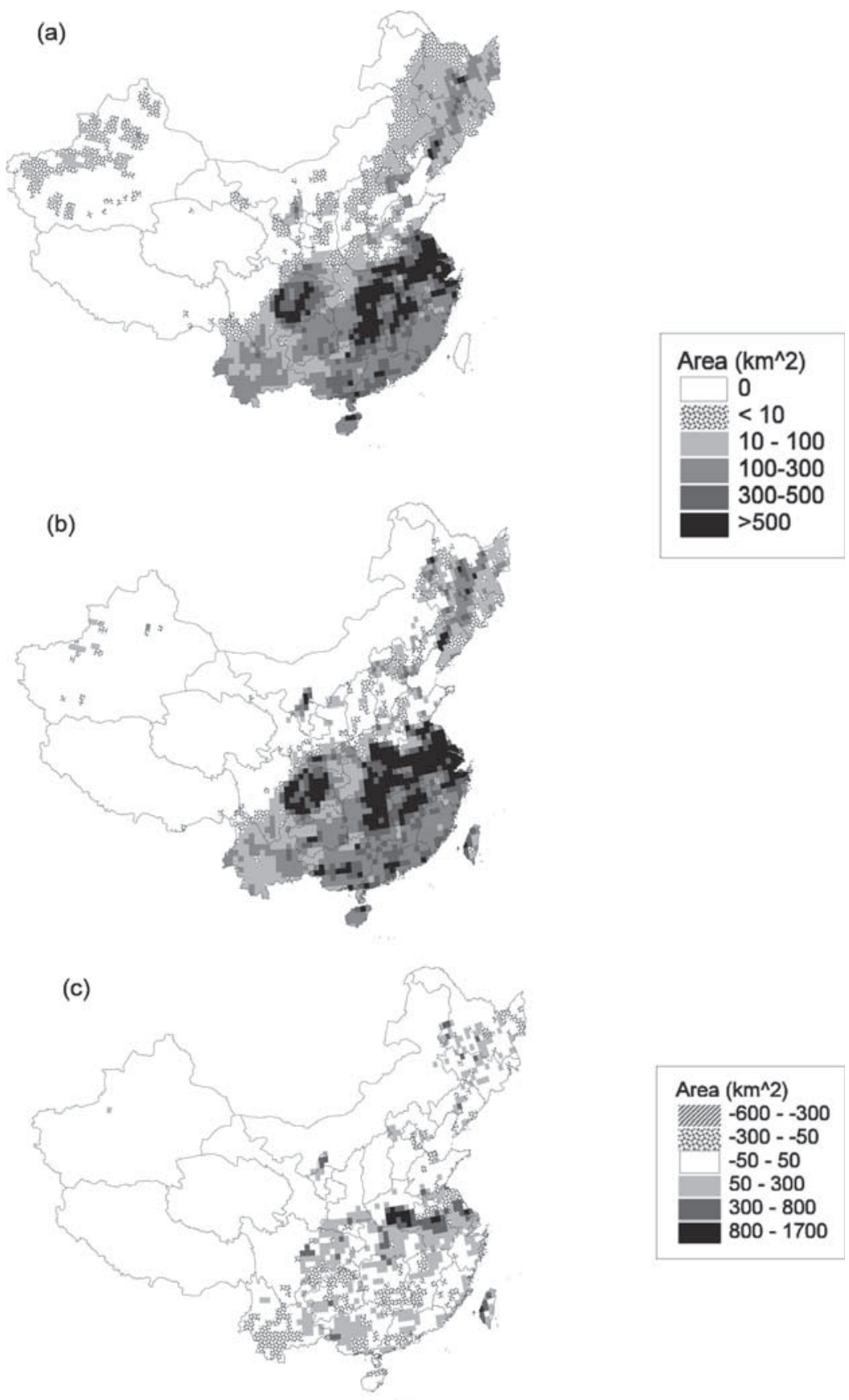

Figure 3. Maps of the distribution of rice crop rotations in China. (a) The sum of Figures 2a-2d; (b) Landsat-derived paddy area (NLCD-96), with no distinction of single or multicropping; and (c) the difference in areas between the Landsat analysis and this study: Figure 3b minus Figure 3a. All maps are $0.5^{\circ}$ resolution, and the gray scale refers to the land area within each grid cell that is classified as paddy land; the top legend (all values $\geq 0$ ) refers to Figures $3 \mathrm{a}$ and $3 \mathrm{~b}$, and the bottom legend refers to Figure 3c. Multicropped land is not weighed more heavily than single-cropped land. Note that only NLCD-96 included paddy areas for Taiwan, and discrepancies in Taiwan in Figure $3 \mathrm{c}$ are an artifact of the missing data in AC90.

1996, we do not believe this uncertainty is large enough to invalidate our overall results. This could be evaluated with either more current county-scale crop census data, or with earlier fine-resolution remote sensing data. We anticipate that more recent crop census data will become available, and we will investigate this possible discrepancy when it does.

[25] The distribution of paddy rice developed by our methodology is very similar to the distribution derived from the land-cover classification of Landsat TM imagery when it 
Table 3. Cropland Areas $\left(10^{6} \mathrm{~km}^{2}\right)$ in Mainland China ${ }^{\mathrm{a}}$

\begin{tabular}{lccc}
\hline & This Study & SSB $^{\mathrm{b}}$ & NLCD-96 $^{\mathrm{c}}$ \\
\hline Rice land area & 0.30 & 0.26 & 0.36 \\
Rice sown area & 0.47 & 0.33 & - \\
Crop land area & 1.32 & 0.95 & 1.32 \\
Crop sown area & 1.98 & 1.48 & - \\
\hline
\end{tabular}

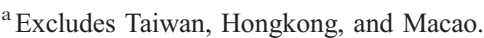

${ }^{\mathrm{b}}$ Official agricultural census statistics for 1990 [SSB, 1994].

${ }^{\mathrm{c}}$ Landsat-derived areas for mid-1990s [Liu et al., 2001].

was aggregated to the same $0.5^{\circ}$ resolution (Figures $3 \mathrm{a}$ and $3 b)$. The main discrepancy between the two maps was in the middle and lower Yangtze River region (Figure 3c). In this region, particularly the southern part of Henan Province, there was extensive cropland. NLCD-96 classified most of the cropland as paddy rice, but our county data reported the majority of the sown area for counties in this area as wheat and maize, so the paddy area was significantly less in our analysis. Official statistics for paddy rice area in Henan Province in 1993 reported that only $6.3 \%$ of cultivated land was rice paddy [SSB, 1994].

[26] This study combined remote sensing and ground census data to develop a synthesis product that incorporates the strengths of each data set. Several other recent studies have combined remote sensing land-cover data with ground census land-use data to generate maps of cropland [Ramankutty and Foley, 1998; Goldewijk, 2001] or general land use categories [Hurtt et al., 2001]. Those studies used moderate-resolution remote sensing products based on the AVHRR (Advanced Very High Resolution Radiometer) instrument (1-km resolution), and very general land-use categories: "Cropland" in the case of the Ramankutty and Foley [1998] and Goldewijk [2001] global maps and "Cropland," "Forest," "Pasture," and "Other" in the case of the Hurtt et al. [2001] map of land-use in the United States. In this current analysis, the resolution of both input data sets is enhanced: The land-cover map is at 1:100 000 resolution, based on Landsat imagery (30-m pixels), and the crop census data has been analyzed to generate fractional-area data for 49 different crop rotations, rather than just an aggregate cropland category. Xiao et al. [2002a] have developed an alternative method to use optical remote sensing both to map paddy fields and to determine the timing of flooding, based on the temporal dynamics of the ratio of the NormalizedDifference Vegetation and Water Indices (NDWI/NDVI). Their analysis requires multiple remote sensing images during a growing season, and has only been applied to a 14-county area near Nanjing, China.

[27] The new maps that have been developed can improve our ability to quantify the cycling of carbon (C) and nitrogen (N) in China's agriculture. Different land management practices can have significant consequences on $\mathrm{C}$ and $\mathrm{N}$ biogeochemistry of agro-ecosystems [Lal et al., 1995; Greenland, 1995]. Fertilizer application, manure amendment, and crop residue incorporation can all vary with crop rotation and associated management practices. This will directly affect $\mathrm{C}$ and $\mathrm{N}$ contents in the soils. Frequency and depth of tillage will vary among different crop rotation regimes. Frequency and duration of flooding of paddy rice fields depends on crop rotation. These will also influence rates of soil organic carbon decomposition [Havlin et al., 1990; Rasmussen and Rohde, 1988], and can significantly affect methane emissions from the soils [Wassmann et al., 2000]. More accurate estimates of the extent and distribution of different crop rotations will lead to improved estimates of $\mathrm{C}$ sequestration and trace gas emissions from these agroecosystems. In an earlier analysis, $\mathrm{Li}$ et al. [2001] used the AC-90 cropland database, combined with estimates of fertilizer use, manure production and application, tilling/ planting/harvesting dates, and daily weather, all spatially resolved at the county scale, to drive a biogeochemical model and generate spatial estimates of $\mathrm{N}_{2} \mathrm{O}$ emissions from China's cropland. The maps developed in this current study increase the cropland area 39\% above the AC-90/SSB values (Table 3), and through a much more thorough treatment of multicropping, increased our estimate of total sown area by about $85 \%$; redoing the model analysis with this new information resulted in a near doubling of the estimated total $\mathrm{N}_{2} \mathrm{O}$ emissions from China's cropland [Li et al., 2002].

[28] These new maps are the first to portray a spatially explicit distribution of a number of single-crop and multicrop rotations for China. The methodology could be used to generate maps for other regions, and at other resolutions, with an absolute lower limit of resolution being the scale of the remote sensing data. However, a practical lower limit would be the scale at which county crop rotation fractions $\left(\beta_{k, n}\right.$ in equation (1)) are representative, which we estimate to be on the order of $10 \mathrm{~km}$ in eastern China and on the order of $50 \mathrm{~km}$ in western China. Also, as more current Chinese agricultural census data and/or more recent remote sensing land cover products become available, these maps can and will be updated. The maps described in this manuscript will be made available on the World Wide Web at http://www.dndc.sr.unh.edu/.

[29] Acknowledgments. This work has been supported by a grant from the multiagency TECO program sponsored by NASA, NSF, DOE, USDA, and EPA. We thank Huajun Tang, Qingmu Chen, Tao Tao, and Shigong Zhang at the Institute of Agricultural Resources and Regional Planning, Chinese Academy of Agricultural Sciences, Beijing, for help with the crop rotation analysis. We also thank Michael Routhier and Stanley Glidden of the UNH Remote Sensing and GIS Laboratory for assistance with the GIS analysis.

\section{References}

Belward, A. S., J. E. Estes, and K. D. Kline, The IGBP-DIS global 1-km land-cover data set DISCover: A project overview, Photogram. Eng. Remote Sens., 65, 1013-1020, 1999.

Colby, W. H., F. W. Crook, and S.-E. H. Webb, Agricultural Statistics of the People's Republic of China, 1949-1990, Stat. Bull. 844, U.S. Dep. Of Agric., Econ. Res. Serv., Washington, D.C., 1992.

Crook, F., Underreporting of China's cultivated land area: Implications for world agricultural trade, in China International Agricultural and Trade Report, Sit. Outlook Ser. RS-93-4, pp. 33-39, U.S. Dep. of Agriculture, Washington, D. C., 1993.

Denier van der Gon, H. A. C., and H. U. Neue, Influence of organic matter incorporation on the methane emission from a wetland rice field, Global Biogeochem. Cycles, 9, 11-22, 1995.

Editorial Committee, Hubei Province Agricultural Statistical Yearbook 1991(in Chinese), Agric. Publ. House, Min. of Agric., Beijing, 1991.

Frolking, S., X. Xiao, Y. Zhuang, W. Salas, and C. Li, Agricultural land-use in China: A comparison of area estimates from ground-based census and satellite-borne remote sensing, Global Ecol. Biogeogr. Lett., 8, 401-416, 1999.

Fu, L. Q., S. W. Zhang, D. W. Liu, and E. P. Wan, Image processing for maize yield estimation by remote sensing (in Chinese), in Remote Sensing 
Technique for Wheat, Maize, and Rice Yield Estimation, edited by B. S. Chen, pp. 8-15, China Sci. and Technol., Beijing, 1993.

Goldewijk, K. K., Estimating global land use change over the past 300 years: The HYDE Database, Global Biogeochem. Cycles, 15, 417433, 2001

Greenland, D. J., Land use and soil carbon in different agroecological zones, in Soil Management and the Greenhouse Effect, edited by R. Lal et al., pp. 9-24, CRC, Boca Raton, Fla., 1995.

Havlin, J. L., D. E. Kissel, L. D. Maddux, M. M. Claassen, and J. H. Long, Crop rotation and tillage effects on soil organic carbon and nitrogen, Soil Sci. Soc. Am. J., 54, 448-452, 1990.

Hurtt, G. C., L. Rosentrater, S. Frolking, and B. Moore, Linking remotesensing estimates of land cover and census statistics on land use to produce maps of land use of the conterminous United States, Global Biogeochem. Cycles, 15, 673-685, 2001.

Lal, R., N. R. Fausey, and D. J. Eckert, Land use and management effects of emissions of radiatively active gases from two soils in Ohio, in Soil Management and the Greenhouse Effect, edited by R. Lal et al., pp. 41-60, CRC, Boca Raton, Fla., 1995.

Li, C., S. Frolking, and R. C. Harriss, Modeling carbon biogeochemistry in agricultural soils, Global Biogeochem. Cycles, 8, 237-254, 1994.

Li, C., Y. H. Zhuang, M. Q. Cao, P. M. Crill, Z. H. Dai, S. Frolking, B. Moore, W. A. Salas, W. Z. Song, and X. K. Wang, Comparing a national inventory of $\mathrm{N}_{2} \mathrm{O}$ emissions from arable lands in China developed with a process-based agro-ecosystem model to the IPCC methodology, Nutr. Cycl. Agroecosys., 60, 159-175, 2001.

Li, C., Y. H. Zhuang, S. Frolking, J. N. Galloway, R. C. Harriss, B. Moore, D. Schimel, and X. K. Wang, Modeling soil organic carbon change in croplands of China, Ecol. Appl., in press, 2002.

Liu, J., (Ed.), Macro-Scale Survey and Dynamic Study of Natural Resources and Environment of China by Remote Sensing (in Chinese), 353 pp., Press of Sci. and Technol., Beijing, 1996.

Liu, M., X. Tang, J. Liu, and D. Zhuang, Research on scaling effect based on $1 \mathrm{~km}$ grid cell data (in Chinese), J. Remote Sens., 5(3), 183-190, 2001.

Loveland, T. R., J. W. Merchant, J. F. Brown, D. O. Ohlen, B. C. Reed, P. Olson, and J. Hutchinson, Seasonal land-cover regions of the United States, Ann. Assoc. Am. Geogr., 85, 339-355, 1995.

Prather, M., R. Derwent, D. Ehhalt, P. Fraser, E. Sanhueza, and X. Zhou, Other trace gases and atmospheric chemistry, in Climate Change 1994, edited by J. T. Houghton et al., pp. 77-126, Cambridge Univ. Press, New York, 1995.

Ramankutty, N., and J. A. Foley, Characterizing patterns of global land-use: An analysis of global croplands data, Global Biogeochem. Cycles, 12, $667-685,1998$

Rasmussen, P. E., and C. R. Rohde, Long-term tillage and nitrogen fertilization effects on organic nitrogen and carbon in a semiarid soil, Soil Sci. Soc. Am. J., 52, 1114-1117, 1988.

Sass, R. L., F. M. Fisher, F. T. Turner, and M. F. Jund, Methane emission from rice fields as influenced by solar radiation, temperature, and straw incorporation, Global Biogeochem. Cycles, 5, 335-350, 1991.

Seto, K. C., R. K. Kaurmann, and C. E. Woodcock, Landsat reveals China's farmland reserves, but they are vanishing fast, Nature, 406, 121, 2000.

Smil, V., China's agricultural land, China Q., 158, 414-429, 1999.
State Statistical Bureau, Statistical Yearbook of China 1994, 795 pp., China Stat. Publ. House, Beijing, 1994.

Tang, X., Studies on geo-spatial data fusion and its applications, Ph.D. dissertation, Institute of Remote Sensing Applications (in Chinese), 139 pp., Chin. Acad. of Sci., Beijing, 2000.

Verburg, P. H., and J. A. C. Denier van der Gon, Spatial and temporal dynamics of methane emissions from agricultural sources in China, Global Change Biol., 7, 31-47, 2001.

Vitousek, P. M., J. D. Aber, R. W. Howarth, G. E. Likens, P. A. Matson, D. W. Schindler, W. H. Schlesinger, and D. G. Tilman, Human alteration of the global nitrogen cycle: Sources and consequences, Ecol. Appl., 7, 737750, 1997

Wassmann, R., R. S. Lantin, H. U. Neue, L. V. Buendia, T. M. Corton, and Y. Lu, Characterization of methane emissions from rice fields in Asia, III, Mitigation options and future research needs, Nutr. Cycl. Agroecosyst., $58,23-36,2000$

Wu, C., (Editor in Chief), Land-Use Map of China (1:1,000,000 scale), Science Press, Beijing (In Chinese), 1990.

Xi, C., (Ed.), Soil of China (in Chinese), Agric. Press, Beijing, 1998

Xiao, X., S. Boles, S. Frolking, W. Salas, B. Moore, C. Li, L. He, and R. Zhao, Observations of flooding and rice transplanting of paddy rice fields at the site to landscape scales in China using VEGETATION sensor data, Int. J. Remote Sens., 23, 3009-3022, 2002a.

Xiao, X., J. Y. Liu, D. F. Zhuang, S. Frolking, S. Boles, B. Xu, M. L. Liu, B. Moore, C. S. Li, and W. Salas, Uncertainties in estimates of cropland area in China: A comparison between an AVHRR-derived dataset and a Landsat TM-derived dataset, submitted to Global and Planetary Change, in press, $2002 b$.

Yuyun, B. I., and Z. Y. Zheng, Actual changes of cultivated area since the founding of the new China (in Chinese), Resour. Sci., 22(2), 8-12, 2000.

Zhang, W., D. Zhuang, and W. Hu, Area summarization in establishing the national resources and environmental database (in Chinese), J. Remote Sens., 4, 304-310, 2000.

Zhuang, Y. H., M. Cao, X. Wang, and H. Yao, Spatial distribution of tracegas emissions from burning crop residue in China, in Biomass Burning and Global Change, vol. 2, edited by J. S. Levine, pp. 764-770, MIT Press, New York, 1996.

S. Boles, S. Frolking, C. Li, and X. Xiao, Institute for the Study of Earth Oceans, and Space, University of New Hampshire, Morse Hall, 35 College Road, Durham, NH 03824, USA. (Stephen.boles@unh.edu; steve.frolking@ unh.edu; changsheng.li@unh.edu; xiangming.xiao@unh.edu)

J. Liu, Institute of Geographical Sciences and Natural Resources, Chinese Academy of Sciences, Anwai, Datun Road, Beijing 100101, China. (Liujy@ igsnrr.ac.cn)

X. Qin, Institute of Geology and Geophysics, Chinese Academy of Sciences, A11 Datun Road, Chaoyang District, Beijing 100101, China. (qinxg@public.east.cn.net)

J. Qiu, Institute of Agricultural Resources and Regional Planning, Chinese Academy of Agricultural Sciences, 30 Baishi QialLu, HaiDian District, Beijing 100081, China. (jjqiu3792@sina.com)

Y. Zhuang, Research Center for Eco-Environmental Sciences, PO Box 2871, Beijing 100085, China. (apcpo@95777.com) 